\title{
The Effect of Mass Building and Shadow Patterns on the Outdoor Thermal Building of Apartment in Surabaya
}

\author{
Beatrice, I. S. \\ Post Graduated \\ Department of Architecture \\ Institut Teknologi Sepuluh Nopember \\ Surabaya, Indonesia
}

\author{
Antaryama, I. G. N. \\ Lecturer \\ Department of Architecture \\ Institut Teknologi Sepuluh Nopember \\ Surabaya, Indonesia
}

\author{
Ekasiwi, S. N. N \\ Lecturer \\ Department of Architecture \\ Institut Teknologi Sepuluh Nopember \\ Surabaya, Indonesia
}

\begin{abstract}
This research was carried out to investigate the influence of building mass along with the generated shading toward the outdoor thermal of apartemen in Surabaya. Building form and open space geometric wich covers $\mathrm{H} / \mathrm{W}$ ratio (Building height/width of open space in building range), orientation and configuration of mass building are choosen as resesearch variable. This study used experiment method with ENVI-emt 4 as the key software. The modeling was taken from typology apartment that already exist in Surabaya. All data from simulation was analyzed with quantitative (mean temperature, wind speed, relative humidity and solar radiation analyzed) method, by using table and graphic to see the preferences wich happen in every category of certain variable. The result of this study shows the influences of mass building on outdoor thermal environment. Minimum temperature on outdoor temperature by square mass building geometric patterns is more effective than parallel patterns, along with $\mathrm{H} / \mathrm{W}$ ratio that give more significant result to reduced the temperature was ratio $\mathrm{H} / \mathrm{W}=6$. The result can be used as design guidlines for the new cities or certain districs and also can applied in existing urban spaces by adding building mass, open spaces and shadowing, and changing shape and orientastion of the open spaces.
\end{abstract}

Keywords- Apartment; H/W ratio; Modelling; Outdoor thermal; Shading

\section{INTRODUCTION}

The outdoor thermal environment of urban street has become a matter concern beacause of urban heat island pehenomena caused by rapid urbanization. Buildings may respond and give different roles in urban environment. For instant, buildings not only contribute as radiation absorber and heat reflector which increase the air temperature, but also the building can be as shading generator to decrease the air temperature [4]. Apartment building is one of high-rise buildings that forming the outdoor environtment. The configuration of these apartments may have potential to generated shading in the outdoor environtment that can reduce the temperature and heat radiation when the mass configuration of buildings is directed and organized by considering the shape of building, site design, and the orientation of building façade [11]. Therefore, it is necessary to study how much the influence of shading by mass geometry of the building along with the generated shading againts thermal outdoor. The location with humid tropical climate such as in Surabaya, Indonesia, can be described by its high air temperature, air humidity, and solar radiation intensity, but low wind speed [10].

Research on relationship between outdoor thermal and microclimate with build environment characteristics has been widely practiced by various researchers. Those researchs can be classified as [1]:

1) Research that study and observe the impact of model physical settings towards outdoor thermal and microclimate $[6,8,13]$.

2) Explorative research that uses real settings [11,14,15].

This study is focused on analyzing and investigating how mass building geometry patterns configuration along with the generated shading influence the outdoor thermal system. Apartment Building Type

There are two building type of apartments that usually be used i.e flat type apartment and tower type. Flat type apartment contains such as typology with straight/elongated type, L-type, and bending type while tower type contains such as $\square$-type, Y-type, and X-type [12].

The Shadow Patterns

Shadow patterns is a patterns that formed on the outdoor surface from direct sun rays that block by landscape cover (buildng, tree etc) [11].

Ratio $\mathrm{H} / \mathrm{W}$ and Orientation

Urban shading on the road is a function of orientation and ratio $\mathrm{H} / \mathrm{W}$. Where increase of the ratio $\mathrm{H} / \mathrm{W}$ can increase shading, so as to decrease the temperature and PET value means it can improve the thermal comfort of outdoor space [7].

\begin{tabular}{|ll|}
\hline Nomenclature \\
$H / \mathrm{W}$ & $\begin{array}{l}\text { Rasio height/weight of open space in building } \\
\text { range }\end{array}$ \\
$R H$ & Relative humidity $[\%]$ \\
$T_{a}$ & Air Temperature $\left[{ }^{\circ} \mathrm{C}\right]$ \\
$\mathrm{V}$ & Wind speed $[\mathrm{m} / \mathrm{s}]$ \\
$I_{D R}$ & Amount of direct solar radiation $[\mathrm{W} / \mathrm{m} 2]$ \\
\hline
\end{tabular}




\begin{tabular}{|c|c|}
\hline \multicolumn{2}{|c|}{ Subscripts } \\
\hline $\mathrm{b}$ & Shaded area \\
\hline $\mathrm{tt}$ & Unshaded area \\
\hline TB & East-West orientation \\
\hline US & North-South orientation \\
\hline $\mathrm{U}$ & Type of typology building with $\mathrm{U}$ form. \\
\hline U1 & $\begin{array}{l}\text { U type building form with square mass building } \\
\text { geometry patterns }\end{array}$ \\
\hline $\mathrm{U} 2$ & $\begin{array}{l}\text { U type building form with parallel mass building } \\
\text { geometry patterns }\end{array}$ \\
\hline $\mathrm{L}$ & Type of typology building with L form \\
\hline L1 & $\begin{array}{l}\text { L type building form with square mass building } \\
\text { geometry patterns }\end{array}$ \\
\hline L2 & $\begin{array}{l}\text { L type building form with parallel mass building } \\
\text { geometry patterns }\end{array}$ \\
\hline & Type of typology building with tower form \\
\hline K1 & $\begin{array}{l}\square \text { type building form with square mass building } \\
\text { geometry patterns }\end{array}$ \\
\hline K2 & $\begin{array}{l}\square \text { type building form with square mass building } \\
\text { geometry patterns }\end{array}$ \\
\hline HW1 & Ratio height/width of open space $=1$ \\
\hline HW3 & Ratio height/width of open space $=3$ \\
\hline HW6 & Ratio height/width of open space $=6$ \\
\hline
\end{tabular}

\section{METHOD}

The research was performed with experiment towards apartment buildings form samples that will be conditioned with variables research, such as ratio height/weight of open space that were $\mathrm{H} / \mathrm{W}=1, \mathrm{H} / \mathrm{W}=3$, and $\mathrm{H} / \mathrm{W}=6$. Orientation variable that were East-West and North-South, and configuration of mass building patterns variable that were parallel and square patterns. The results of apartment buildings samples that were used by this experiment was type of typology building form that have been widely used in Surabaya, which are building form with geometry type L, U, and square with 20 floors height (table 1) as a base case.

TABLE I. APARTMENT BUILDING SAMPLES

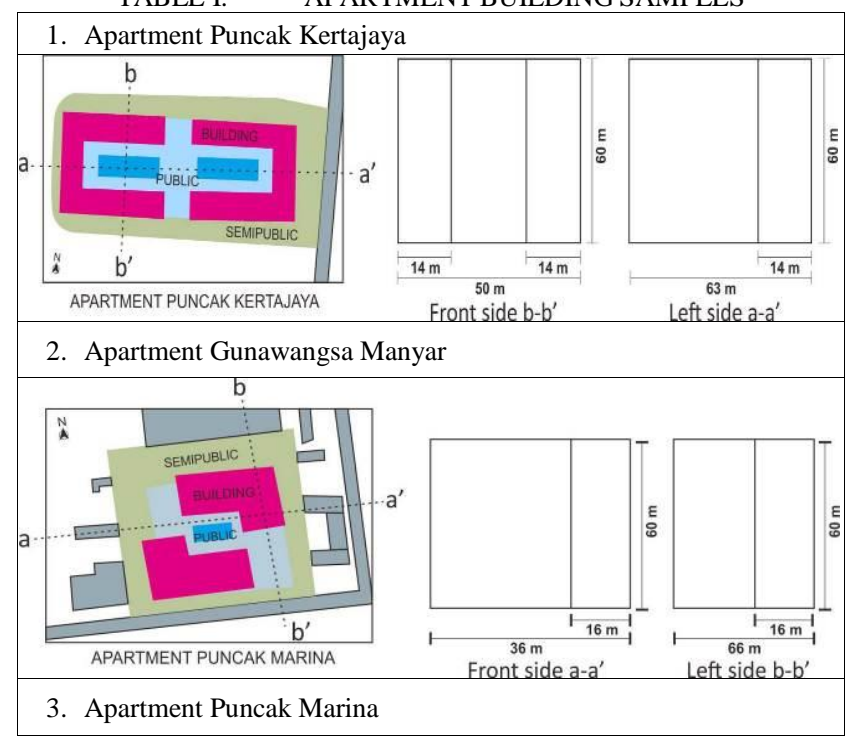

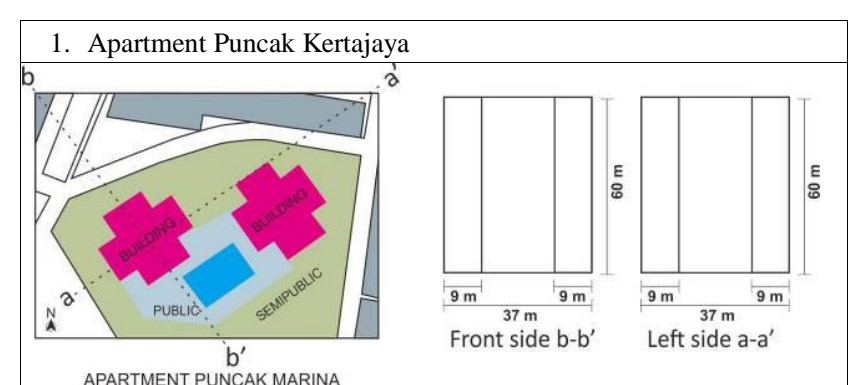

TABLE II. MODEL DESCRIPTION

\begin{tabular}{|l|l|l|}
\hline \multicolumn{3}{|l|}{ 1. Ground Cover } \\
\hline & Existing & Model Simulation \\
\hline $\begin{array}{l}\text { Ground } \\
\text { cover } \\
\text { component }\end{array}$ & $\begin{array}{l}\text { There is no huge difference between existing and model } \\
\text { simulation. The difference was model simulation are only } \\
\text { use paving as the surface material and there's no vegetation }\end{array}$ \\
\hline Building & Eksisting building & $\begin{array}{l}\text { Building form can only } \\
\text { be a block and flat roof }\end{array}$ \\
\hline $\begin{array}{l}\text { Asphalt,veg } \\
\text { etation, } \\
\text { paving, and } \\
\text { soil }\end{array}$ & $\begin{array}{l}\text { There is asphalt, vegetation (tree } \\
\text { and grass), and paving as cover } \\
\text { ground on the apartment } \\
\text { buildings }\end{array}$ & $\begin{array}{l}\text { The ground cover is } \\
\text { restricted only using } \\
\text { paving as surface } \\
\text { material as around } \\
\text { apartment building }\end{array}$ \\
\hline 2. Orientation, H/W ratio, and mass building patterns \\
\hline Orientation & $\begin{array}{l}\text { There is no huge difference between existing and model } \\
\text { simulation. The difference was only there's 2 orientation } \\
\text { (East-West and North-South) that will be used in model } \\
\text { simulation as comparison between configuration of mass } \\
\text { building patterns. }\end{array}$ \\
\hline H/W ratio & $\begin{array}{l}\text { There is no huge difference between existing and model } \\
\text { simulation. The difference is just in model simulation will be } \\
\text { use three ratio (H/W=1, H/W=3, and H/W=6) that will be } \\
\text { conditioned into configuration of mass building patterns }\end{array}$ \\
\hline $\begin{array}{l}\text { Mass } \\
\text { building } \\
\text { patterns }\end{array}$ & $\begin{array}{l}\text { The mass building } \\
\text { Eatterns that will be } \\
\text { Eksisting patterns } \\
\text { used are square patterns } \\
\text { (center) and parallel } \\
\text { patterns (elongated) }\end{array}$ \\
\hline
\end{tabular}

The ground cover in model simulation is restricted only using paving as surface material on the open space, with no natural element landscape cover (tree, soil, or grass), in order to focusing generated shading is originally come from building massif without regard to the external factor such as vegetation or contour as well as surface soil moisture.

TABLE III. DESIGN MODEL EXPERIMENT

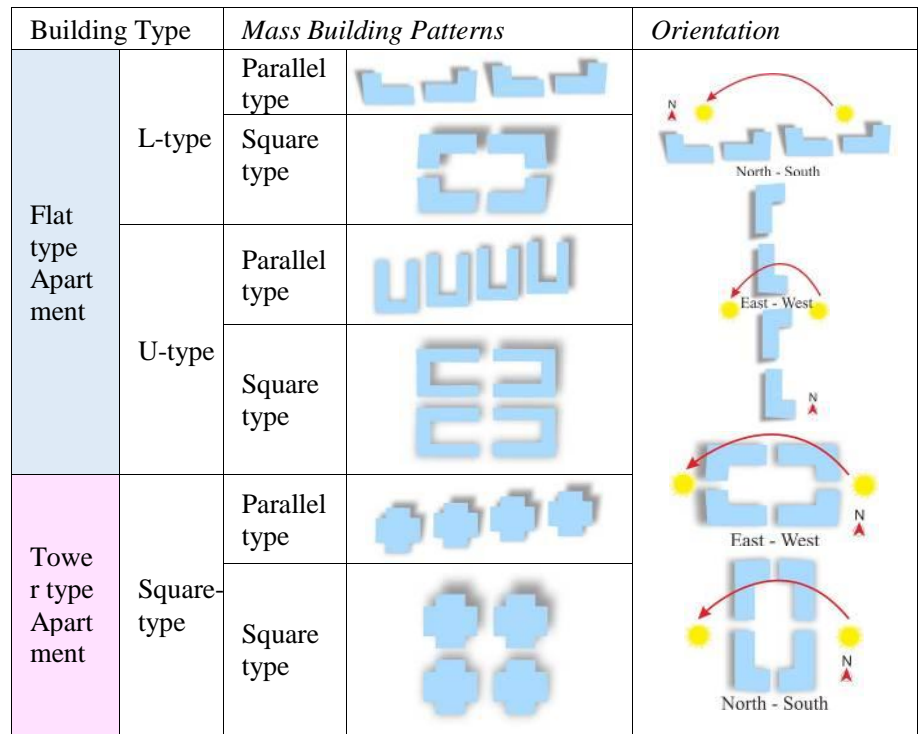


Each patterns on model experiment (Table III) will be conditioned with ratio $\mathrm{H} / \mathrm{W}$ variable that already explained before. The experiment was done by using software ENVI-met 4 as the key software.

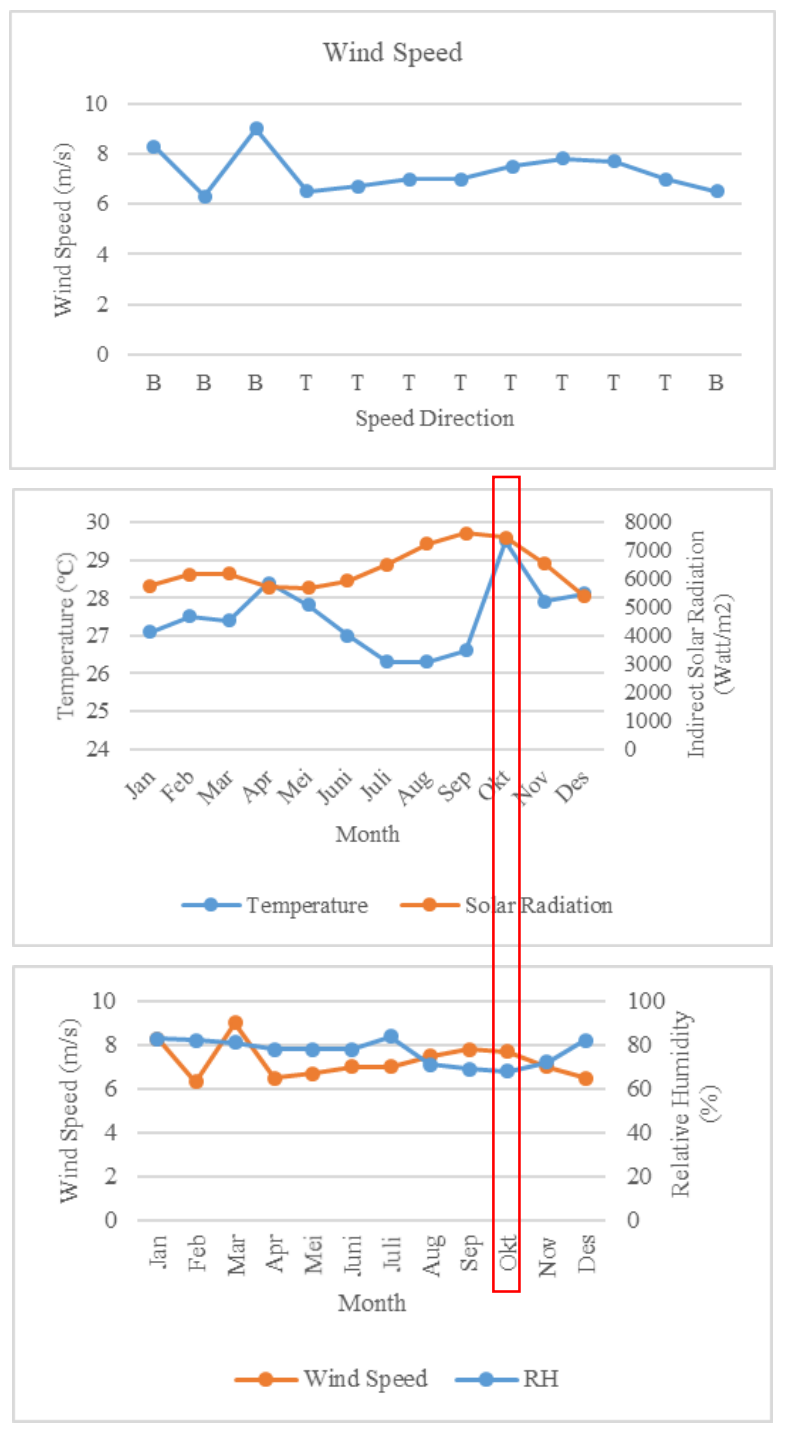

Fig. 1. Macroclimate of Surabaya 2012

Macro climate data was analysed in order to determine the extreme time throughout the year that will used for the measurement time for simulation in all configuration of mass building. Based on Fig. 1, it is known that in 2012 the highest average $T_{a}$ was in Oktober with $29,5{ }^{\circ} \mathrm{C}$ and the lowest $T_{a}$ occured in July-August with $26,3{ }^{\circ} \mathrm{C}$. $R H$ levels almost always stable throughout January to July and decrease from August to October. The highest $R H$ occurs in July-August and the lowest in Oktober, where $R H$ ranges from $68-84 \%$. The highest $V$ occured in March and decreased until May and was fairly stable in range $\pm 7 \mathrm{~m} / \mathrm{s}$ untuk November. Average $V$ speed in Surabaya ranges from $6,5-9,0 \mathrm{~m} / \mathrm{s}$ and comes from East.

\section{A. Field measurement at Apartment Gunawangsa Manyar}

Microclimate was analysed in order to find the characteristic of field measurement in real condition as a verification for experimental methods that was done by using simulation software. Field measurement were conducted on November 19-28-2017, in Gunawangsa Manyar apartment. In terms of measurement results, mean $\mathrm{Ta}$ in Gunawangsa Manyar was $\leq 30{ }^{\circ} \mathrm{C}$ in each days, this is related to when the measurement were conducted the weather tend to be cloudy and overcast. This can be seen at the graphic direct solar radiation. There is trend pattern of $T a$ movement where the tendency of $T a$ increased drastically began to seen since 11.00 until noon and decreased drastically since 18.00 when the sun was down. The highest $T a$ tend to be happen 2-3 hours after $12.00 \mathrm{pm}$. The increasing and decreasing intensity of solar radiation affects the increase and decrease of air temperature.

The average $V$ in Gunawangsa Manyar was $\leq 2 \mathrm{~m} / \mathrm{s}$, and moving indefinitely every hour. The trend show $V$ in Gunawangsa Manyar is tend to increase from morning to noon and decrease at afternoon till night. The $R H$ in Gunawangsa have trend of movement patterns increased in the afternoon till morning and decreased since 08.00 until noon.

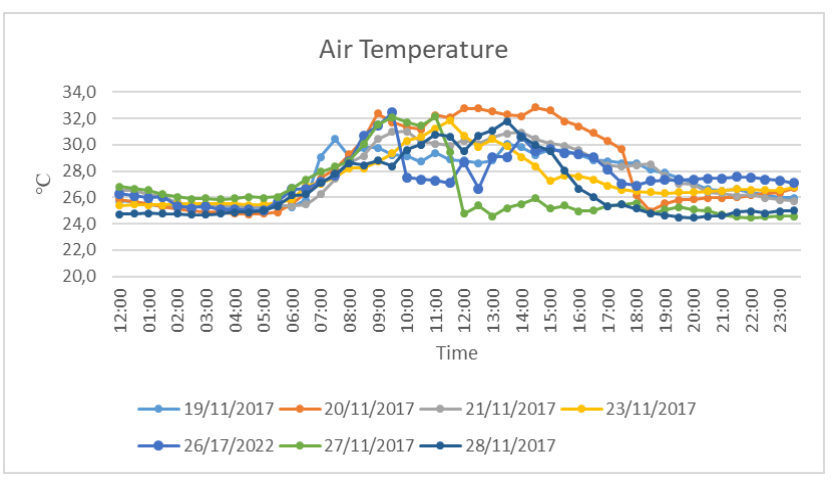

(a)

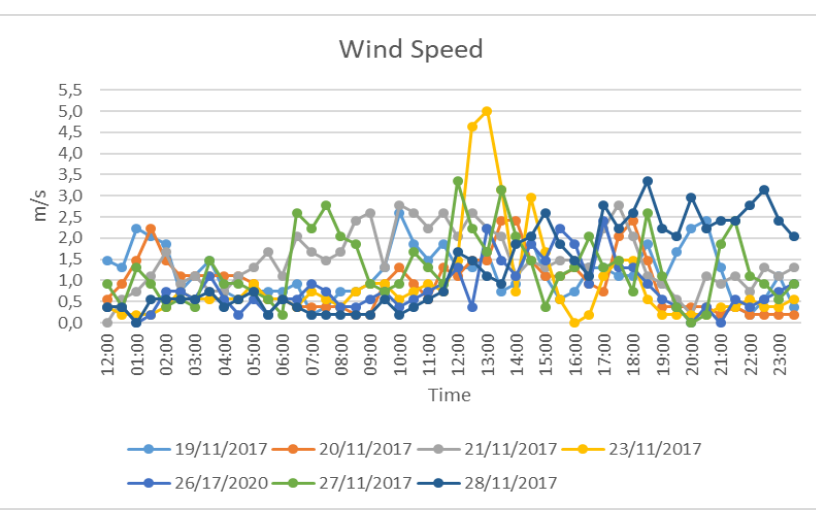

(b)

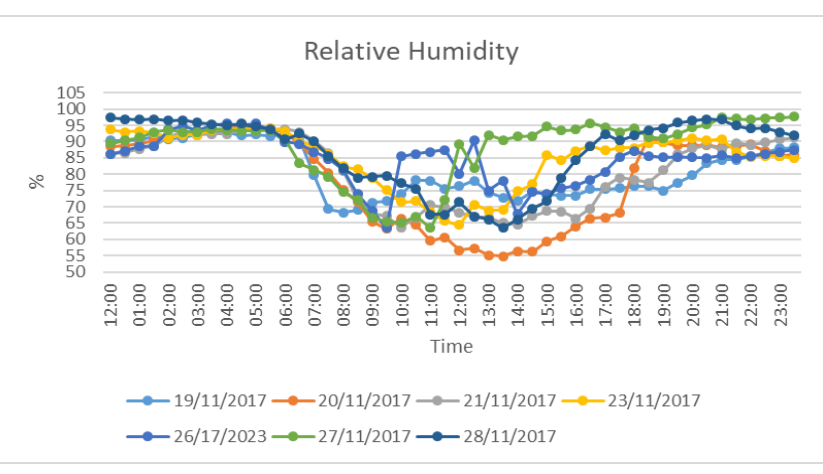


(d)

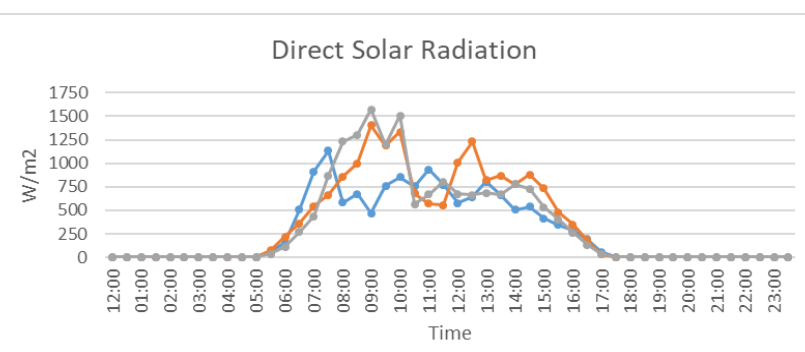

Fig. 2. Measured of $(a) \mathrm{Ta},(b) \mathrm{V},(c) \mathrm{RH}$, and $(d) \mathrm{I}_{\mathrm{DR}}$ at Gunawangsa Manyar Apartment on 19-28 November 2017
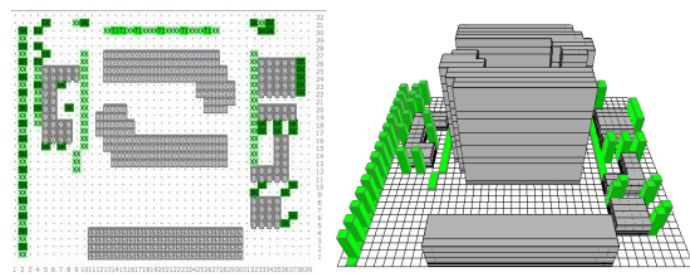

Fig. 3. Apartment Gunawangsa Manyar Model Simulation

\section{B. Model validation result}

Fig. 4 shows that in modelled measured and field measured have similar trends on the $T a, R H$ and $I_{D R}$. The only difference was at wind speed which this is can be caused by the simulation model simplification and the data input that inserted in simulation is from data macro of Surabaya climate 2012. Based on the tendency that occurs in the field, it's also seen in simulation results, where the tendency of temperature movement is almost the same as the pattern of movement in the field, where temperatures tend to rise from the morning until noon in accordance with rising intensity values of solar radiation.

The movement of wind speed is inversely proportional to the humidity of the air. The orientation of the road / area is related to the pattern of building mass in acquisition of wind velocity, which can lead to deflection and changes in wind speed on the outdoor apartment. But at Gunawangsa Manyar's apartment, the two free sides that are not obstructed by their respective buildings lead to the East-West direction, it is advantageous in getting the wind flow due to the direction of the wind.

Temperature in model simulation results has the hottest peak result at 14.00 with $T a$ value is $30,2{ }^{\circ} \mathrm{C}$, slightly cooler than the field measured condition at the same hour that is 30-32 ${ }^{\circ} \mathrm{C}$. Bruse research (2009) states that there is a difference in field air temperature results and simulation results $2-4{ }^{\circ} \mathrm{C}$. However, the range of differences in the study is not absolute, there is still tolerance, so that the deviation value still within the limits of deviation and the simulation using ENVI-met software can be used further.

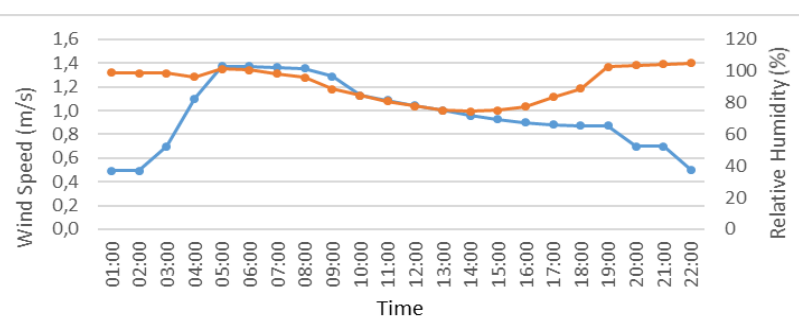

(a)

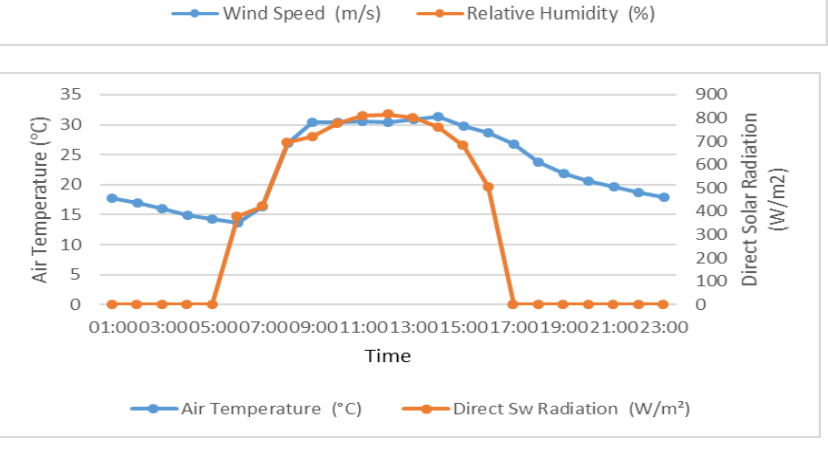

Fig. 4. Measured of moedelled Gunawangsa Apartment by ENVI-met

\section{RESULT AND ANALYSIS}

Analysis data consisting of several stages i.e. analysis of shading, thermal environment, and the effect of configuration of mass building design along with the generated shading towards outdoor thermal environment.

\section{A. Experimental modelled simulation of $U 1$ results}

The percentage of shading that generated by the square pattern on $\mathrm{U}$ type is mostly found in the East-West orientation with low $\mathrm{H} / \mathrm{W}$ value $(\mathrm{H} / \mathrm{W}=1)$. This is because at the time of the hottest month (October) the sun's position is on the South side, so the East-West oriented road is more profitable in providing more shading [4]. So does the shape of building geometry type $\mathrm{U}$ where the facade side extends North-south towards the East-West orientation of the building pattern affecting the percentage of the shading produced as well. The highest percentage shading occurred in the morning at 07.00 and the lowest occurred at 12:00 when the sun is perpendicular to the surface of earth.

(a)

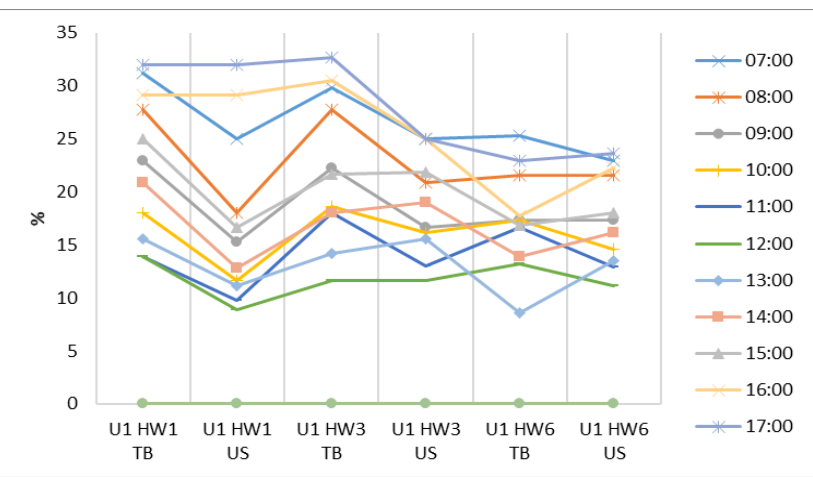




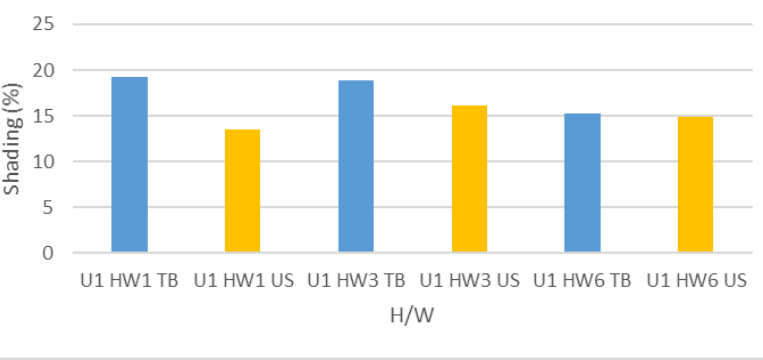

(b)

Fig. 5. Measured of shading percentage at U1 (a) per hour and (b) per ratio

Type of geometry $\mathrm{U}$ in square patterns with $\mathrm{H} / \mathrm{W}=1$ has the higher shading precentage with orientation on East-West due to the elongated side of façade building type $U$ has NorthSouth orientation direction. The pattern of shading presentage movement tends to have pattern that is inversely proportional to the intensity of solar radiation and air temperature. Table IV showed that U1 HW6 US has the minimum temperature compared to other mass building patterns with high avg. $V(7,5$ $\mathrm{m} / \mathrm{s}$ ). While U1 HW6 TB has the minimum temperature although the avg. $V$ is quite low $(4,9 \mathrm{~m} / \mathrm{s})$, this is occurred because this configuration is is more effected by shading. The shading in outdoor on the road is a function of the orientation and comparison of $\mathrm{H} / \mathrm{W}$ values. Where the reduction of shading of the building ( $\mathrm{H} / \mathrm{W}$ value) can reduce air temperature [7].

TABLE IV.

\begin{tabular}{|c|c|c|c|c|c|c|c|}
\hline \multicolumn{2}{|c|}{$\begin{array}{l}\text { Thermal } \\
\text { Condition }\end{array}$} & \multicolumn{6}{|c|}{ Mass Building Patterns } \\
\hline & & $\begin{array}{l}\text { U1 } \\
H W 1 \\
T B\end{array}$ & $\begin{array}{l}U 1 \\
H W 1 \\
U S\end{array}$ & $\begin{array}{l}1 \\
H W 3 \\
T B\end{array}$ & $\begin{array}{l}\text { U1 } \\
H W 3 \\
U S\end{array}$ & $\begin{array}{l}\text { U1 } \\
H W 6 \\
T B\end{array}$ & $\begin{array}{l}\text { U1 } \\
H W 6 \\
\text { US }\end{array}$ \\
\hline \multirow{3}{*}{$\begin{array}{l}\mathrm{Ta} \\
\left({ }^{\circ} \mathrm{C}\right)\end{array}$} & Min & 23,6 & 23,6 & 22,8 & 22,6 & 23,5 & 22,4 \\
\hline & Max & 32,9 & 32,5 & 31,4 & 31,8 & 31,0 & 31,8 \\
\hline & Avg. & 29,0 & 29,0 & 28,6 & 27,8 & 27,9 & 27,8 \\
\hline \multirow{3}{*}{$\begin{array}{c}V \\
(\mathrm{~m} / \mathrm{s})\end{array}$} & Min & 5,8 & 5,9 & 9,5 & 7,9 & 3,6 & 6,9 \\
\hline & Max & 6,4 & 6,3 & 9,8 & 8,3 & 4,9 & 7,5 \\
\hline & Avg. & 6,1 & 6,1 & 9,5 & 8,2 & 4,3 & 7,2 \\
\hline \multirow{3}{*}{$\begin{array}{l}R H \\
(\%)\end{array}$} & Min & 40 & 40 & 53,7 & 53 & 48 & 57 \\
\hline & Max & 80 & 78 & 86 & 87 & 80 & 88 \\
\hline & Avg. & 59 & 58 & 70 & 70 & 64 & 73 \\
\hline
\end{tabular}

B. Experimental modelled simulation of $U 2$

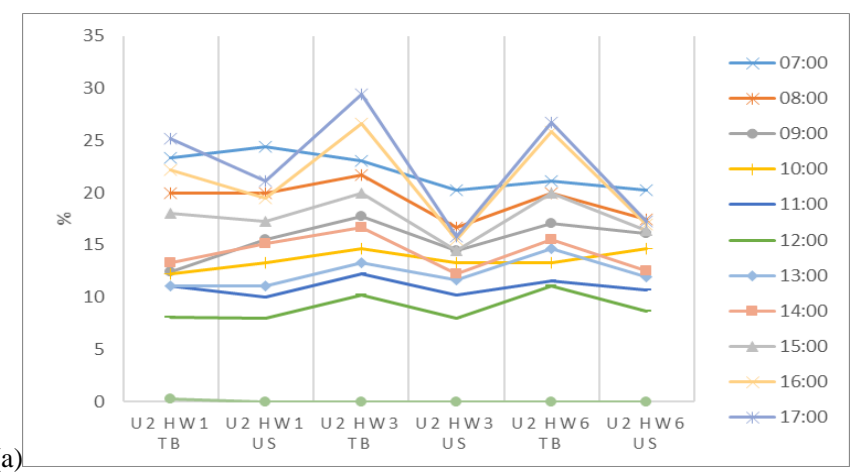

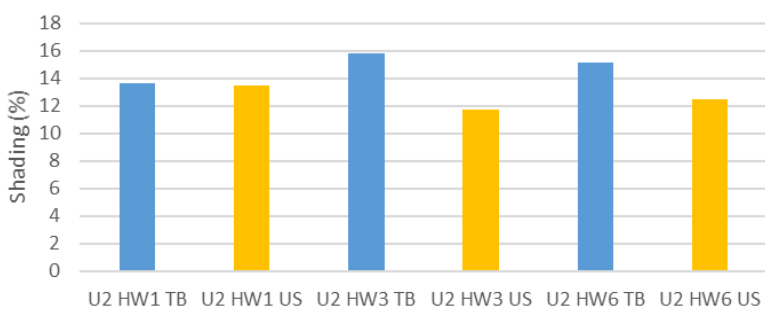

(b)

Fig. 6. Measured of shading percentage at U2 (a) per hour and (b) per ratio

When compared to the overall parallel patterns, building masses in type $U$ with US orientation has the same avg. percentage of shading with $\mathrm{TB}$ orientation in $\mathrm{H} / \mathrm{W}=1$. While the highest percentage of shading is on orientation TB with ratio $\mathrm{H} / \mathrm{W}$ value of 3 . Table $\mathrm{V}$ showed that $\mathrm{U} 2 \mathrm{HW} 6 \mathrm{US}$ has the minimum temperature $\left(28,3{ }^{\circ} \mathrm{C}\right)$ even though the avg. $V$ is low $(2,2 \mathrm{~m} / \mathrm{s})$. This is occurred because influenced of the shading due to in $\mathrm{H} / \mathrm{W}=6$ have a narrow road so the shading on the corridor si more effective. There is significant influence of $\mathrm{H} / \mathrm{W}$ value on thermal reception and thermal environment in outdoor [7]. This is related to the $\mathrm{H} / \mathrm{W}$ and road orientation values are fundamental factors in the design parameters in generating the percentage of the shading and the movement of wind flow (wind direction and wind velocity) [7,4].

TABLE V. COMPARISON OF THERMAL CONDITIONS IN U2

\begin{tabular}{|c|c|c|c|c|c|c|c|}
\hline \multicolumn{2}{|c|}{$\begin{array}{l}\text { Thermal } \\
\text { Condition }\end{array}$} & \multicolumn{6}{|c|}{ Mass Building Patterns } \\
\hline & & $\begin{array}{l}U 2 \\
H W 1 \\
T B\end{array}$ & $\begin{array}{l}U 2 \\
H W 1 \\
U S \\
\end{array}$ & $\begin{array}{l}U 2 \\
H W 3 \\
T B \\
\end{array}$ & $\begin{array}{l}U 2 \\
H W 3 \\
U S \\
\end{array}$ & $\begin{array}{l}U 2 \\
H W 6 \\
T B \\
\end{array}$ & $\begin{array}{l}U 2 \\
H W 6 \\
U S \\
\end{array}$ \\
\hline \multirow{3}{*}{$\begin{array}{l}T a \\
\left({ }^{\circ} \mathrm{C}\right)\end{array}$} & Min & 23,6 & 24,1 & 23,4 & 23,4 & 23,6 & 23,3 \\
\hline & Max & 34,0 & 32,5 & 32,7 & 31,9 & 32,4 & 32,0 \\
\hline & Avg. & 29,6 & 29,0 & 28,8 & 28,3 & 28,7 & 28,3 \\
\hline \multirow{3}{*}{$\begin{array}{c}V \\
(\mathrm{~m} / \mathrm{s})\end{array}$} & Min & 6,2 & 1,5 & 7,2 & 2,3 & 7,9 & 2,1 \\
\hline & Max & 6,5 & 2,0 & 7,8 & 2,5 & 8,6 & 2,3 \\
\hline & Avg. & 6,2 & 1,6 & 7,4 & 2,4 & 8,2 & 2,2 \\
\hline \multirow{3}{*}{$\begin{array}{l}R H \\
(\%)\end{array}$} & Min & 40 & 42 & 43 & 48 & 44 & 49 \\
\hline & Max & 80 & 77 & 81 & 81 & 80 & 82 \\
\hline & Avg. & 61 & 60 & 63 & 65 & 62 & 66 \\
\hline
\end{tabular}

\section{Experimental modelled simulation of $L 1$ results}

Fig. 7 showed that L1 and TB orientation has higher shading percentage in all ratio $\mathrm{H} / \mathrm{W}$. The highest percentage shading occurred in the morning at 07.00 both in square and parallel patterns. The lowest occurred at 12:00 when the sun is perpendicular to the surface of earth. L1 HW3 TB has the most minimum temperature $\left(28,0^{\circ} \mathrm{C}\right)$ with avg. $V 2,2 \mathrm{~m} / \mathrm{s}$. This occurred due to elongated side of façade building type $\mathrm{L}$ has orientation that directed on East-West, which mostly blocked the wind velocity that come from East. The condition when the temperature was low even though the wind velocity was also low is occured because this configuration is more affected by shading. The shading in outdoor on the road is a function of 
the orientation and comparison of $\mathrm{H} / \mathrm{W}$ values. Where the reduction of shading of the building $(\mathrm{H} / \mathrm{W}$ value) can reduce air temperature [7].

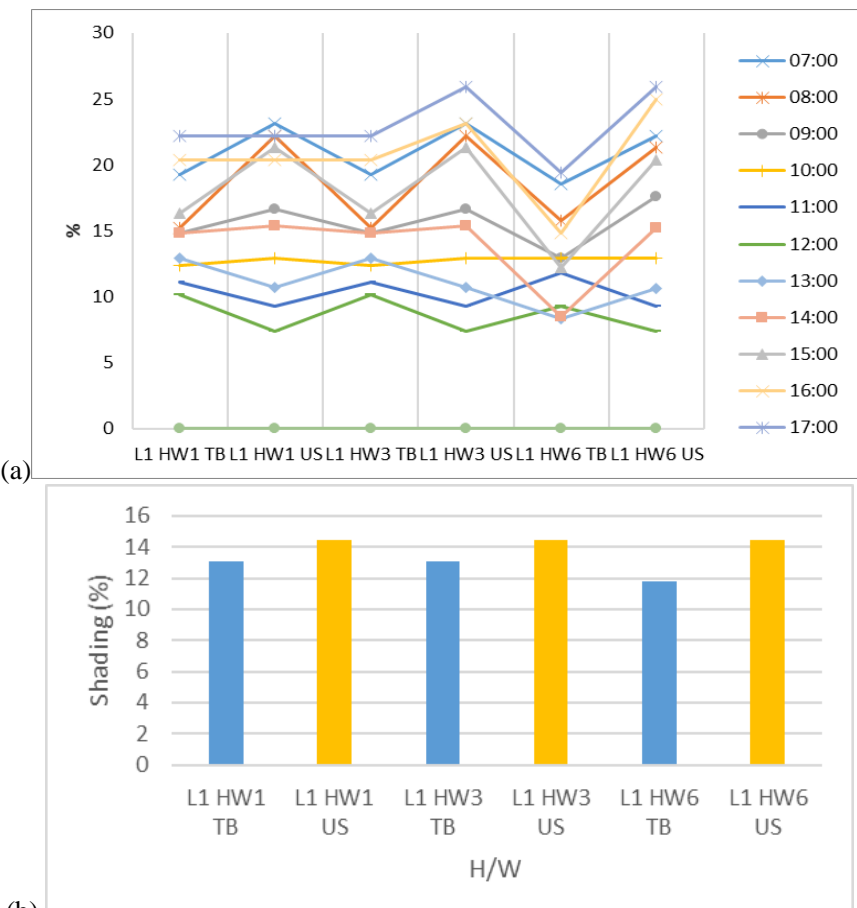

Fig. 7. Measured of shading percentage at L1 (a) per hour and (b) per ratio

Fig. 8 showed ratio with $\mathrm{H} / \mathrm{W}$ value 1 has the highest percentage of shading on TB orientation and the lowest is in ratio $\mathrm{H} / \mathrm{W}=6$ on $\mathrm{US}$ orientation. Although the minimum temperature has occurs in ratio $\mathrm{H} / \mathrm{W}=6$. This condition occured because high wind velocity in this configuration is quite high $(7,3 \mathrm{~m} / \mathrm{s})$. An increase in the aspect ratio of building (H/W) / road geometry and the percentage of built areas can significantly decrease the thermal conditions during the day $[4,7,9,11]$. To be able provide a comfortable wind speed required a minimum $\mathrm{H} / \mathrm{W}$ value of 2 for North-South orientation but there needs to be a distance between the buildings. As for the orientation of East-West road requires at least the value of $\mathrm{H} / \mathrm{W} \geq 4$ to be able to provide a comfortable wind [9].

\begin{tabular}{|c|c|c|c|c|c|c|c|}
\hline \multirow{2}{*}{\multicolumn{2}{|c|}{$\begin{array}{l}\text { TABLE VI. } \\
\text { Thermal } \\
\text { Condition }\end{array}$}} & $\mathrm{COMH}$ & RISON & THER & ALCC & DITIC & IS IN L1 \\
\hline & & \multicolumn{6}{|c|}{ Mass Building Patterns } \\
\hline & & $\begin{array}{l}L 1 \\
H W 1 \\
T B\end{array}$ & $\begin{array}{l}L 1 \\
H W 1 \\
U S\end{array}$ & $\begin{array}{l}L 1 \\
H W 3 \\
T B\end{array}$ & $\begin{array}{l}\text { L1 } \\
H W 3 \\
\text { US }\end{array}$ & $\begin{array}{l}1 \\
H W 6 \\
T B\end{array}$ & $\begin{array}{l}\text { L1 } \\
H W 6 \\
\text { US }\end{array}$ \\
\hline \multirow{3}{*}{$\begin{array}{l}\mathrm{Ta} \\
\left({ }^{\circ} \mathrm{C}\right)\end{array}$} & Min & 23,7 & 23,3 & 23,7 & 23,4 & 24,8 & 24,4 \\
\hline & Max & 33,5 & 34,0 & 30,9 & 32,7 & 30,9 & 31,5 \\
\hline & Avg & 29,4 & 29,4 & 28,0 & 28,8 & 28,3 & 28,6 \\
\hline \multirow{3}{*}{$\begin{array}{c}V \\
(\mathrm{~m} / \mathrm{s})\end{array}$} & Min & 3,4 & 5,2 & 2,1 & 6,6 & 0,7 & 4,9 \\
\hline & Max & 3,7 & 6,8 & 2,2 & 6,8 & 1,1 & 5,5 \\
\hline & Avg & 3,5 & 6,0 & 2,2 & 6,7 & 0,8 & 5,2 \\
\hline \multirow{3}{*}{$\begin{array}{l}R H \\
(\%)\end{array}$} & Min & 37 & 37 & 51 & 43 & 50 & 50 \\
\hline & Max & 79 & 82 & 79 & 81 & 75 & 79 \\
\hline & Avg & 57 & 59 & 65 & 63 & 63 & 65 \\
\hline
\end{tabular}

D. Experimental modelled simulation of L2 results

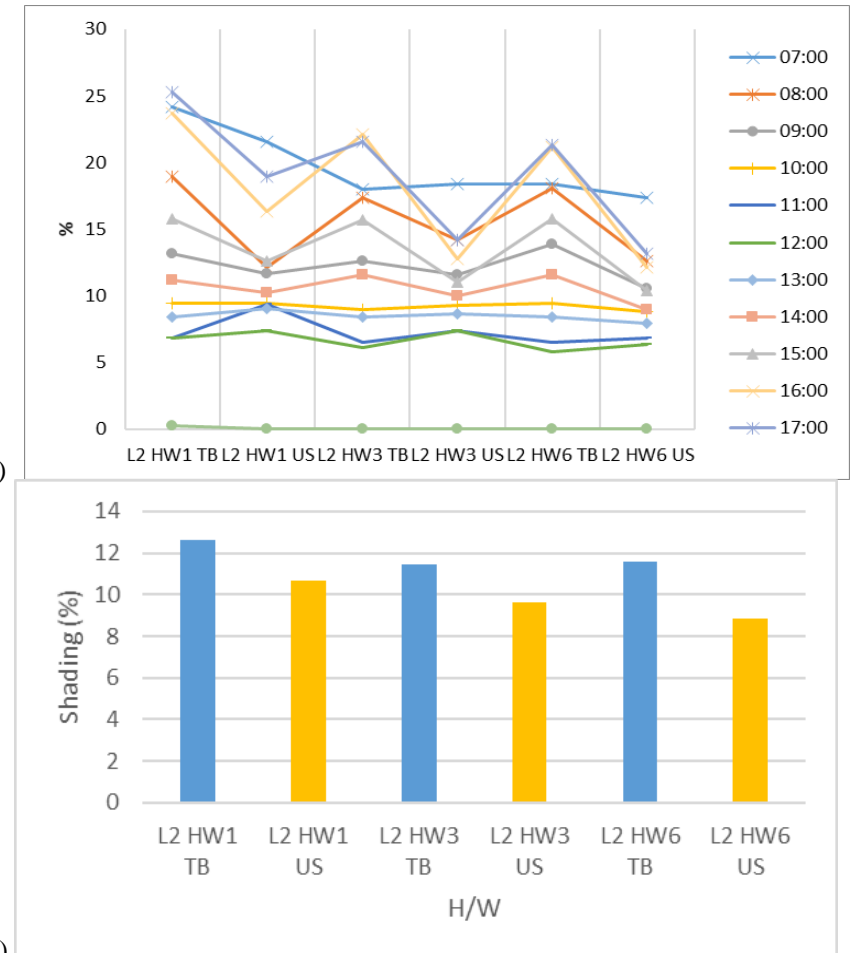

Fig. 8. Measured of shading percentage at L2 (a) per hour and (b) per ratio

L2 HW1 TB has the highest shading percentage other than configuration of mass building patterns with $\pm 12 \%$. Most of configuration with TB orientation have higher shading percentage than US orientation (Fig. 8). While L2 HW6 US has the most minimum temperature $\left(28,6^{\circ} \mathrm{C}\right)$ with avg. $V$ is $1,7 \mathrm{~m} / \mathrm{s}$. This condition occurred because the configuration is more affected by shading. Where the reduction of shading of the building (H/W value) can reduce air temperature [7].

TABLE VII. COMPARISON OF THERMAL CONDITIONS IN L2

\begin{tabular}{|c|c|c|c|c|c|c|c|}
\hline \multicolumn{2}{|c|}{$\begin{array}{l}\text { Thermal } \\
\text { Condition }\end{array}$} & \multicolumn{6}{|c|}{ Mass Building Patterns } \\
\hline & & $\begin{array}{l}2 \\
H W 1 \\
T B \\
\end{array}$ & $\begin{array}{l}L 2 \\
H W 1 \\
U S \\
\end{array}$ & $\begin{array}{l}22 \\
H W 3 \\
T B \\
\end{array}$ & $\begin{array}{l}L 2 \\
H W 3 \\
U S \\
\end{array}$ & $\begin{array}{l}L 2 \\
H W 6 \\
T B \\
\end{array}$ & $\begin{array}{l}\text { L2 } \\
H W 6 \\
U S\end{array}$ \\
\hline \multirow{3}{*}{$\begin{array}{l}\mathrm{Ta} \\
\left({ }^{\circ} \mathrm{C}\right)\end{array}$} & Min & 23,5 & 24,3 & 22,3 & 23,8 & 23,0 & 24,0 \\
\hline & Max & 34,2 & 33,3 & 33,3 & 32,1 & 33,5 & 31,8 \\
\hline & Avg. & 29,7 & 30,0 & 28,9 & 28,7 & 29,1 & 28,6 \\
\hline \multirow{3}{*}{$\begin{array}{c}V \\
(\mathrm{~m} / \mathrm{s})\end{array}$} & Min & 7,2 & 1,5 & 8,0 & 2,2 & 7,0 & 1,7 \\
\hline & $\operatorname{Max}$ & 7,5 & 1,6 & 8,6 & 2,3 & 7,6 & 1,8 \\
\hline & Avg. & 7,3 & 1,5 & 8,3 & 2,3 & 7,3 & 1,8 \\
\hline \multirow{3}{*}{$\begin{array}{l}R H \\
(\%)\end{array}$} & Min & 39 & 37 & 44 & 45 & 44 & 45 \\
\hline & $\operatorname{Max}$ & 81 & 76 & 82 & 79 & 84 & 78 \\
\hline & Avg. & 59 & 58 & 70 & 70 & 64 & 73 \\
\hline
\end{tabular}




\section{E. Experimental modelled simulation of $K 1$ results}

(a)
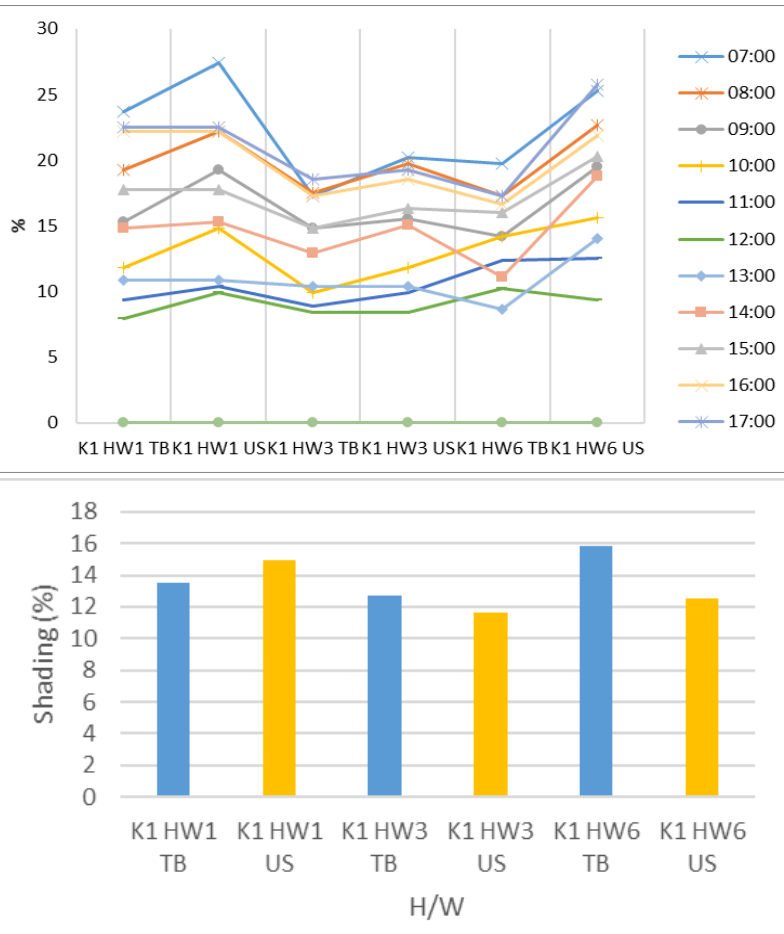

(b)

Fig. 9. Measured of shading percentage at K1 (a) per hour and (b) per ratio

Fig.9 showed that K1 H6 TB has the highest shading percentage on TB orientation, while K1 HW1 US has the highest shading percentage on US orientation. The minimum temperature occurred in $\mathrm{H} / \mathrm{W}=6$ with $27,5^{\circ} \mathrm{C}$ and avg. $V$ is 7,7 $\mathrm{m} / \mathrm{s}$. The highest temperature occurred in $\mathrm{H} / \mathrm{W}=1$ on US orientation $\left(29,3^{\circ} \mathrm{C}\right)$ with avg. $V$ is $5,7 \mathrm{~m} / \mathrm{s}$. This is occured because the orientation of the US road has a high profitable in the acquisition of wind speed because of the direction with the wind coming direction and the acquisition percentage of shading [2].

TABLE VIII. COMPARISON OF THERMAL CONDITIONS IN K1

\begin{tabular}{|c|c|c|c|c|c|c|c|}
\hline \multicolumn{2}{|c|}{$\begin{array}{l}\text { Thermal } \\
\text { Condition }\end{array}$} & \multicolumn{6}{|c|}{ Mass Building Patterns } \\
\hline & & $\begin{array}{l}K 1 \\
H W 1 \\
T B \\
\end{array}$ & $\begin{array}{l}K 1 \\
H W 1 \\
U S \\
\end{array}$ & $\begin{array}{l}K 1 \\
H W 3 \\
T B \\
\end{array}$ & $\begin{array}{l}K 1 \\
H W 3 \\
U S\end{array}$ & $\begin{array}{l}K 1 \\
H W 6 \\
T B \\
\end{array}$ & $\begin{array}{l}\text { K1 } \\
W W 6 \\
U S \\
\end{array}$ \\
\hline \multirow{3}{*}{$\begin{array}{l}\mathrm{Ta} \\
\left({ }^{\circ} \mathrm{C}\right)\end{array}$} & Min & 23,9 & 23,6 & 23,3 & 23,2 & 22,7 & 22,5 \\
\hline & Max & 32,3 & 33,4 & 31,2 & 31,7 & 31,7 & 32,1 \\
\hline & Avg & 28,7 & 29,3 & 28,4 & 28,3 & 27,6 & 27,5 \\
\hline \multirow{3}{*}{$\begin{array}{c}V \\
(\mathrm{~m} / \mathrm{s})\end{array}$} & Min & 2,8 & 5,3 & 7,5 & 8,7 & 6,5 & 7,5 \\
\hline & Max & 3,3 & 6,1 & 7,8 & 8,9 & 7,0 & 7,9 \\
\hline & Avg & 3,2 & 5,7 & 7,7 & 8,8 & 6,8 & 7,7 \\
\hline \multirow{3}{*}{$\begin{array}{l}R H \\
(\%)\end{array}$} & Min & 48 & 37 & 45 & 46 & 57 & 62 \\
\hline & Max & 78 & 79 & 82 & 83 & 86 & 89 \\
\hline & Avg & 63 & 55 & 62 & 63 & 72 & 76 \\
\hline
\end{tabular}

\section{$F$. Experimental modelled simulation of $K 2$ results}
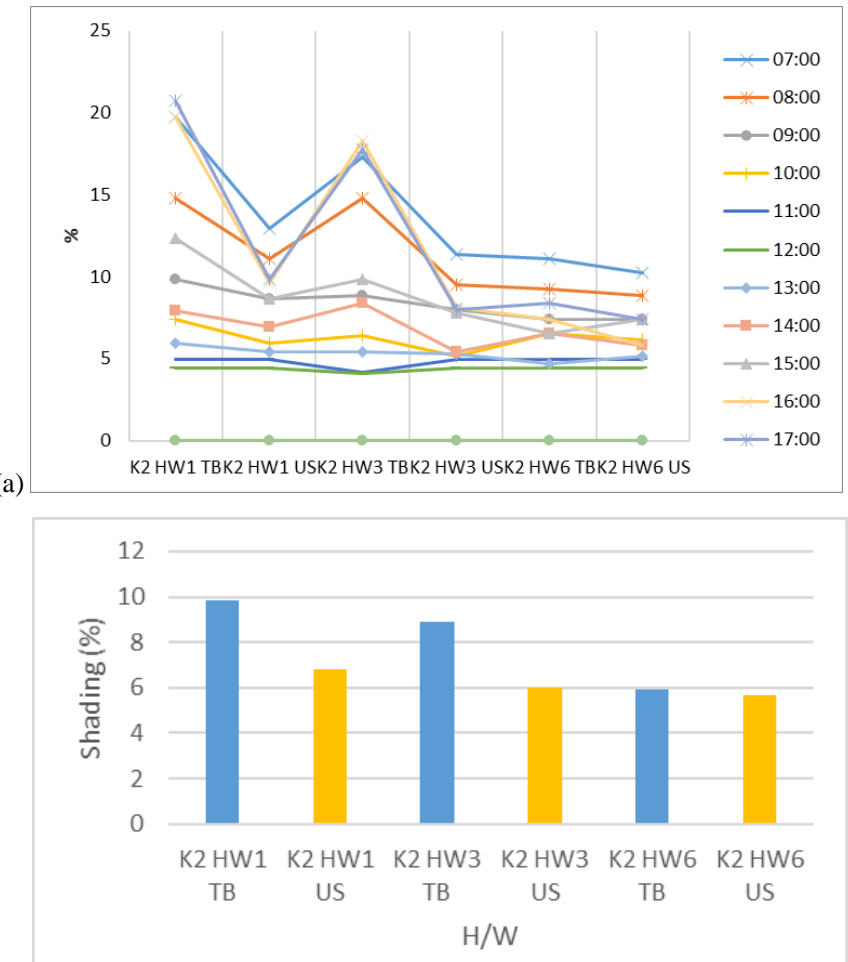

(b)

Fig. 10. Measured of shading percentage at K2 (a) per hour and (b) per ratio

Configuration of mass building pattern with TB orientation have the higher shading percentage than US orientation (Fig.10). To adapt the microclimate by providing a spot that is exposed to sunlight in buildings and troroar, for the East-West side facade needs to involve the use of asymmetrical plants or buildings Ratio [4]. H/W with value 6 has the minimum temperature with $27,7{ }^{\circ} \mathrm{C}$ and avg. $V 3,2 \mathrm{~m} / \mathrm{s}$. This condition was almost the same with L2 HW6 US which occurred because the configuration is more affected by shading. The shading on the road is a function of the orientation and comparison of $\mathrm{H} / \mathrm{W}$ values. Where the reduction of shading of the building (H/W value) can reduce air temperature [7].

TABLE IX. COMPARISON OF THERMAL CONDITIONS IN K2

\begin{tabular}{|c|c|c|c|c|c|c|c|}
\hline \multicolumn{2}{|c|}{$\begin{array}{l}\text { Thermal } \\
\text { Condition }\end{array}$} & \multicolumn{6}{|c|}{ Mass Building Patterns } \\
\hline & & $\begin{array}{l}K 2 \\
H W 1 \\
T B\end{array}$ & $\begin{array}{l}K 2 \\
H W 1 \\
U S \\
\end{array}$ & $\begin{array}{l}K 2 \\
H W 3 \\
T B\end{array}$ & $\begin{array}{l}K 2 \\
H W 3 \\
U S \\
\end{array}$ & $\begin{array}{l}\text { K2 } \\
H W 6 \\
T B\end{array}$ & $\begin{array}{l}K 2 \\
H W 6 \\
U S \\
\end{array}$ \\
\hline \multirow{3}{*}{$\begin{array}{l}\mathrm{Ta} \\
\left({ }^{\circ} \mathrm{C}\right)\end{array}$} & Min & 23,5 & 24,5 & 23,5 & 24,1 & 23,9 & 23,8 \\
\hline & Max & 33,0 & 31,3 & 31,9 & 31,2 & 30,5 & 30,7 \\
\hline & Avg. & 28,9 & 28,8 & 28,4 & 28,1 & 27,7 & 27,9 \\
\hline \multirow{3}{*}{$\begin{array}{c}V \\
(\mathrm{~m} / \mathrm{s})\end{array}$} & Min & 6,1 & 1,0 & 5,5 & 1,0 & 2,8 & 1,4 \\
\hline & Max & 6,6 & 1,5 & 6,1 & 1,3 & 3,3 & 1,6 \\
\hline & Avg. & 6,3 & 1,2 & 5,8 & 1,1 & 3,2 & 1,5 \\
\hline \multirow{3}{*}{$\begin{array}{l}R H \\
(\%)\end{array}$} & Min & 40 & 41 & 43 & 44 & 48 & 47 \\
\hline & Max & 81 & 74 & 80 & 76 & 78 & 79 \\
\hline & Avg. & 60 & 53 & 62 & 60 & 63 & 63 \\
\hline
\end{tabular}


G. Effect of configuration mass building design along with generated shading towards outdoor thermal environment

On the chart that shows thermal condition each building mass pattern and the correlation with the shading that generated from the mass building as well as the thermal conditions in the outdoor due to the modification of mass configuration of the building and its shading can be explained as follows:

- The H/W and orientation values have the most significant relationship to thermal decreases and increases in the outdoor associated with the reception of solar radiation, and wind velocity.

- Condition of air temperature. The increased air temperature is more influenced by the components of the land cover area of apartment building but the decrease in air temperature is more influenced by the orientation of the road, the $\mathrm{H} / \mathrm{W}$ and the mass buidling pattern.

- Wind speed conditions. The increasing of wind speed is more influenced by the comparison of $\mathrm{H} / \mathrm{W}$ and building mass arrangement.

- The intensity conditions of solar radiation tend to be influenced by the shading that generated by apartment buildings geometry (road orientation and building mass patterns).

It can be concluded that between these design parameters (Building mass pattern, $\mathrm{H} / \mathrm{W}$ value, and shading) are not separately affecting thermal outdoor conditions of apartment building. This means that the role of mass building patterns as shading and intensity of solar radiation barrier to the thermal conditions on the outdoor beyond answered. However, to see how and the design parameters (configuration of mass building patterns and the shading generated) are most dominant in influencing the thermal environment system in the outer space so as to achieve optimization of the mass configuration of apartment buildings that allows better closure as a form of imagery in reducing the ambient temperature explained below.

- On U type configuration. The square pattern is more effective in reducing the thermal conditions in outer space with the $\mathrm{H} / \mathrm{W} \geq 1(\mathrm{H} / \mathrm{W}=3$ and $\mathrm{H} / \mathrm{W}=6)$ values and the largest shadow pattern has a square pattern at $\mathrm{H} / \mathrm{W}=1$ for \pm $19 \%$ with TB Orientation. While the parallel pattern required H/W minimum 6 to be able to reduce the air temperature on the outdoor with the orientation of EastWest.

- On L-type configuration. The square pattern is more effective in reducing the thermal conditions in the outer space with the $\mathrm{H} / \mathrm{W} \geq 1(\mathrm{H} / \mathrm{W}=3$ and $\mathrm{H} / \mathrm{W}=6)$ values and the largest shadow pattern is occurred in square pattern in US orientation in every $\mathrm{H} / \mathrm{W}$ ratio. While the parallel pattern required H/W minimum 6 to be able to lower the air temperature in outdoor with US orientation.

- $\quad$ On $\square$ type configuration. Both square and parallel patterns have more effective degradation of thermal outdoor with minimum H/W value of 6 in either US or TB orientation. The largest shadow pattern is in parallel pattern of the H/W ratio $=6$ which is $16 \%$ on US orientation.

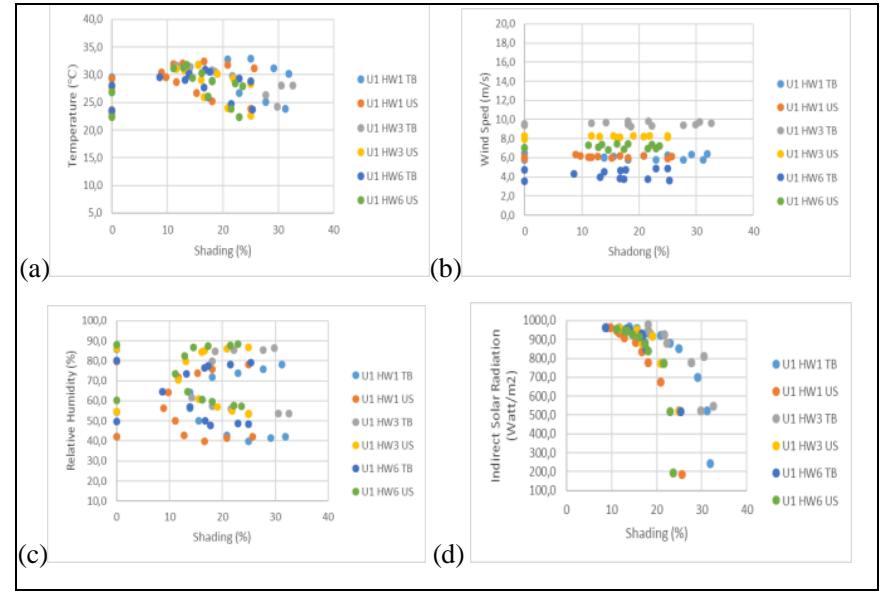

Fig. 11. Corelation of measured temperature (a), temperature (b), wind speed (c), and relative humidity(d) and shading in U1

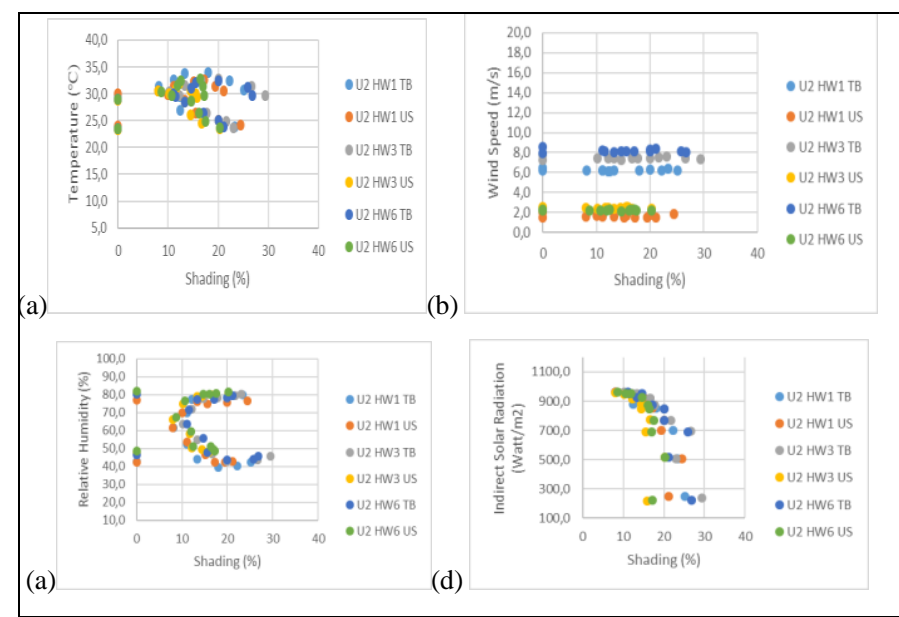

Fig. 12. Corelation of measured temperature (a), temperature (b), wind speed (c), relative humidity(d) and shading in $\mathrm{U} 2$

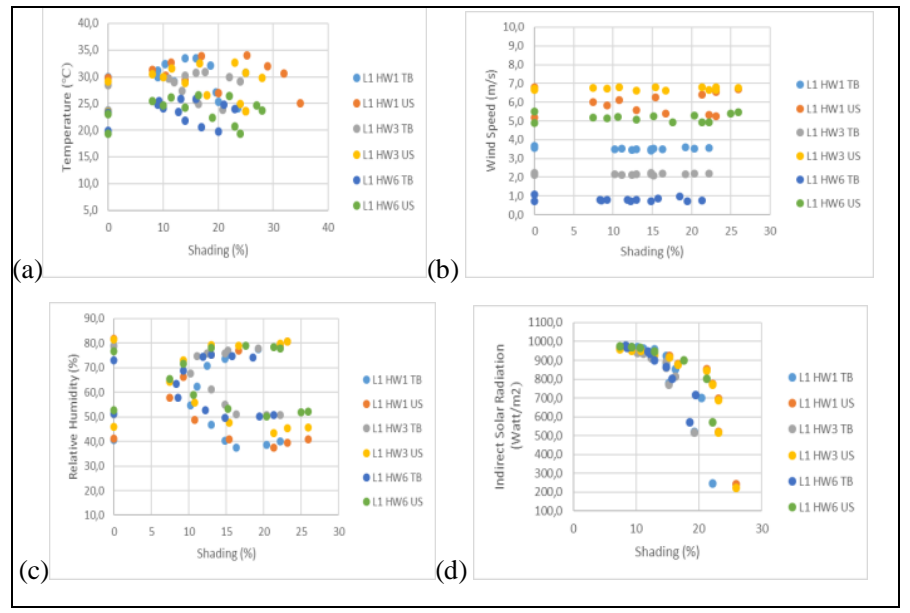

Fig. 13. Corelation of measured temperature(a), temperature (b), wind speed (c), relative humidity (d) and shading in L1 


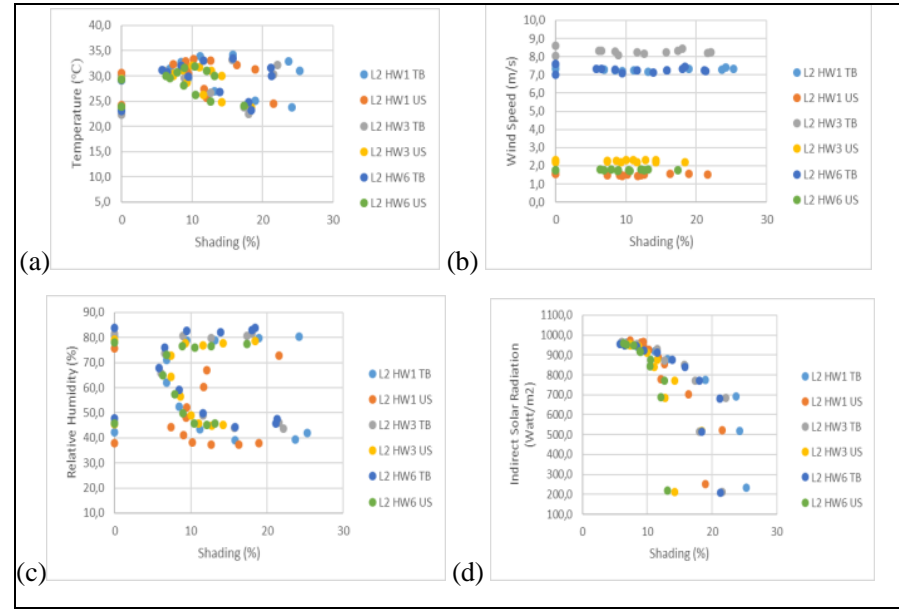

Fig. 14. Corelation of measured temperature (a), temperature (b), wind speed (c), relative humidity(d) and shading in L2

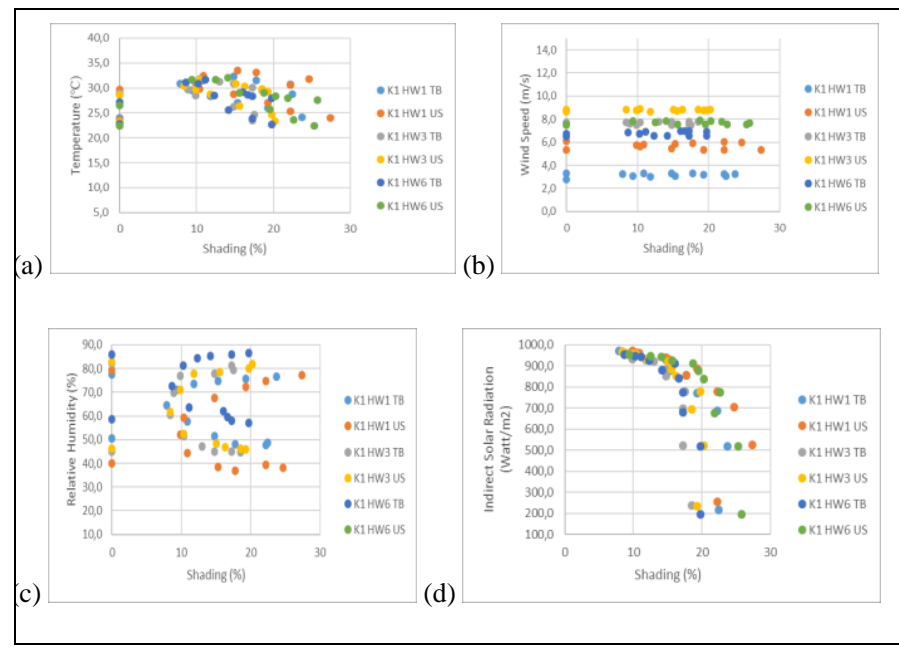

Fig. 15. Corelation of measured temperature and shading (a), temperature (b), wind speed (c), and relative humidity (d) in $\mathrm{K} 1$

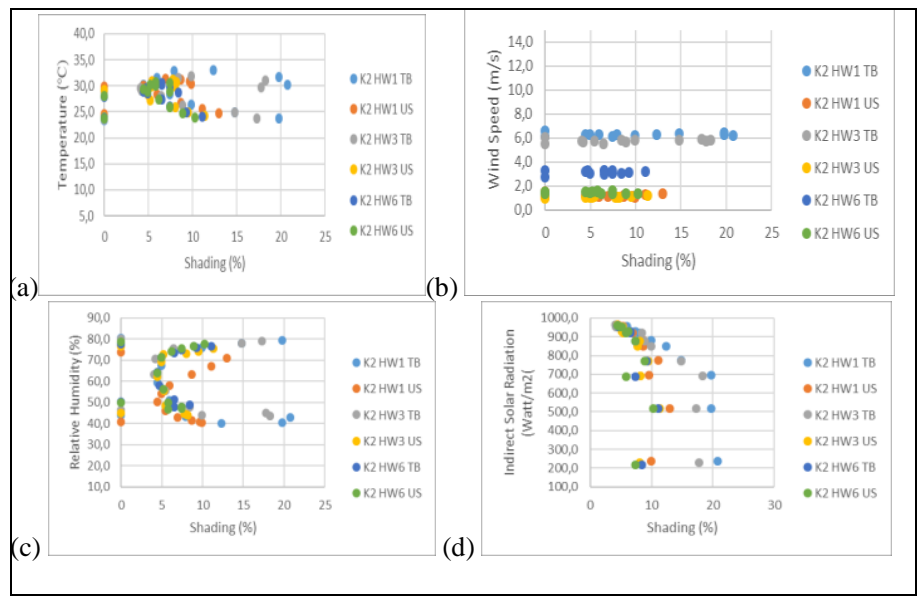

Fig. 16. Corelation of measured temperature (a), temperature (b), wind speed (c), relative humidity(d) and shading in $\mathrm{K} 2$

Based on the analysis above, it can be concluded that the influence of shading on outdoor thermal conditions will have a positive effect if the building as a component of land cover that can generate shading lies in the proper arrangement of building masses that is on orientation of East-West road where the side façade of building geometry occured on road orientation of East-West. This is because the building with East-West oriented road is more advantageous with the influence of the geometry shape of the building with type flat apartment, because on the mass pattern of this type of building the elongated side of facade building is facing North-South facade, so the shading was produced more. North-South orientation with high ratio $\mathrm{H} / \mathrm{W}$ values is advantageous in lowering the air temperature, compared to the East-West orientation with small $\mathrm{H} / \mathrm{W}$ values, but in the tropics this EastWest orientation is advantageous in the acquisition of wind speed because the wind tends from the East and the West [2].

\section{DISCUSSION}

The results of shading generated by each mass building pattern will give effect to different conditions. This depends on the aspect ratio $\mathrm{H} / \mathrm{W}$ and the orientation of the building. On the simulation results of the thirty-six building mass patterns indicate the low temperature conditions in the areas of $\mathrm{H} / \mathrm{W}$ with value 6 both on US and TB orientation with deviation 0,1 $0,5{ }^{\circ} \mathrm{C}$. On parallel mass building pattern on US and TB oriented road is necessary to decrease the $\mathrm{H} / \mathrm{W}$ value to increase the percentage of shading produced by the building. But on the analysis above the higher percentage of shading was not solely lowering the temperatur on outdoor but the density between buildings consider the acquisition of wind speed. Especially in the city of Surabaya with the wind coming direction that tends to come from East or West. So it can be concluded to produce the right shade to be able to lower the air temperature of the building there is need other parameters of design parameters, such as orientation, mass building pattern, and $\mathrm{H} / \mathrm{W}$ ratio.

On square patterns of type $U$ and $L$ tend to have broad shading compared of $\square$ type with the same pattern. However, in lowering the temperature with shading it is necessary to consider other parameters besides the percentage of shading, such as building mass configuration (relation to $\mathrm{H} / \mathrm{W}$ and orientation). This will affect other climatic elements that affect the thermal conditions. US oriented mass building pattern has the minimum temperatur, but on case in square pattern with the orientation of East-West with value of $\mathrm{H} / \mathrm{W}=3$ and $\mathrm{H} / \mathrm{W}=6$, where although the orientation of the road is in the East-West but due to high $\mathrm{H} / \mathrm{W}$ value, this configuration still profitable in the acquisition of broad shading also to reduce air temperature. As Emmanuel et al explains that the shadow in the outdoor in urban (urban shading) on the road is a function of the orientation and comparison of $\mathrm{H} / \mathrm{W}$ values. Where the reduction of imagery of the building $(\mathrm{H} / \mathrm{W}$ value) can reduce air temperature [7].

Based on the results of the above experiment, an explanation of the effect of mass building patterns along with the generated shading towards the thermal condition on the outdoor, as follows:

- The H/W and orientation values have the most significant relationship to thermal decreases and increases in the outdoor associated with the reception of solar radiation, wind direction and wind velocity.

- Building mass with square pattern indicate the low temperature conditions in the areas of East-West orientated. This is because the orientation of the EastWest road has a high profitable in the acquisition of 
wind speed because of the direction with the wind coming direction and the acquisition percentage of shading.

- On parallel pattern is highly indicate the low temperatur is occured in North-South This is occured because the building with North-South oriented road is more advantageous with the influence of the geometry shape of the building with type flat apartment, because the mass pattern of this type of building the elongated side of facade building is facing North-South facade, so the shading was produced more.

\section{CONCLUSION}

Based on the studies that have been done, several conclusions about the outdoor thermal conditions due to the configuration of the building mass along with the generated shading can be explained as follows:

- Mass Building Patterns.

The square pattern is more effective both in reducing the thermal conditions on outdoor and in getting the higher percentage of shading compared with the parallel pattern in each type of apartment type geometry. Different results occur on type $\square$ where both parallel and square patterns with $\mathrm{H} / \mathrm{W}=6$ have an effective minimum temperature.

\section{- $\mathrm{H} / \mathrm{W}$ ratio}

$\mathrm{H} / \mathrm{W}$ ratio in both parallel and square patterns configurations that most effectively lowering the ambient temperature is in the ratio with $\mathrm{H} / \mathrm{W}=6$. Where in this ratio, solar radiation reception tends to be slightly due to the width of the road that is not too wide so that the shading pattern tends to clump and evenly on the corridor area of the ratio $\mathrm{H} / \mathrm{W}=6$, although the percentage of shading tends to be small.

\section{- Orientation}

North-South orientation is more effective both in obtaining a large percentage of shading as well as lowering the thermal conditions in outer space in all types of typology and mass building patterns. On $\square$ type configuration, both square and parallel patterns have more effective on lowering temperature with a minimum H/W value of 6 in either East-West or North-South orientation.

\section{ACKNOWLEDGMENT}

The author would like to thank all the lab architecture's family for supporting this research and also the counsellors who always provide good feedback. And last hanks to my family for the never ending encouragement.

\section{REFERENCES}

[1] Ahmed, Khandaker Shabbir, (2003), "Comfort in urban spaces: defining the boundaries of outdoor thermal comfort for the tropical urban environments", Energy and Buildings, Vol.35; 103-110

[2] Ali-Toudert, F. - Mayer, H. (2007). "Effects of asymmetry, galleries, overhanging fac ades and vegetation on thermal comfort in urban street canyons", Solar Energy, Vol. 81; 742-754

[3] Arnfield, A.,(2003), Two Decades of Urban Climate Research: a Review of Turbulance Exchanges of Energy and Water and The Urban Heat Island, International Journal of Climatology, Vol. 21 Issue 1; 1-26.

[4] Bahar, F. F., (2017), Model Pembayangan dan Lansekap Ruang Kota Dalam Sistemn Lingkungan Termal Perkotaan di Daerah Tropis Lembab.

[5] Bruse, M., M. Bürger, A. Bohnstedt, A. Ihde, K. Jesionek, E. Lahme, (2002). "Measurements and model simulations in WP MICRO RuhrUniversity Bochum, Institute of Geography, Research Group"

[6] Dotulong, Alex Lexi W.H., (2008), Pengaruh Pembayangan Massa Bangunan Terhadap Radiasi Panas Matahari Di Ruang Terbuka Kawasan Tropis Yang Terletak Pada Garis Lintang $7^{\circ} \mathrm{LS}$, Vol 3, No. 1 1-11.

[7] Emmanuel, Rohinton (1997), Summertime Heat Island Effect of Urban Design Parameters, Ph.D. dissertation, University of Michigan, Ann Arbor, USA.

[8] Jeong, Seon-Yeong and Yoo, Seong-Hwan (2012), "Method to Quantify the Effect of Apartment Housing Design Parameters on Outdoor Thermal Comfort in Summer", Building and Environment, Vol 53: 150158

[9] Johansson, Erik (2006), Urban Design and Outdoor Thermal Comfort in Warm Climates Studies in Fez adn Colombo, Grahns Tryckeri AB, Lund, Sweden.

[10] Givoni, Baruch (1998), Climate Considerations in Building and Urban Design, Van Nostrand Reinhold, New York.

[11] Lippsmeier, Georg (1994), Bangunan Tropis (terj.), Erlangga, Jakarta

[12] Makaremi, Nastaran et.al. (2011), Thermal Conditions of Shaded Outdoor Spaces in Hot and Humid Climate of Malaysia, Building and Environtment; 48; 7-14.

[13] Pagalla, Apriany Griffin (2013), Visualiasasi Pola Pembayangan pada Sentra Niaga Swarga Bara di Sangatta, Kalimantan Timur, Universitas Brawijaya.

[14] Purnomo, A. Budi (2003), Pengaruh Bayangan dan Bangunan Vegetas pada Suhu Udara di Kampus A, Universitas Trisakti, Dimensi Teknik Asitektur, Vol31, No. 2; 152-257.

[15] Widiyanto, Eka (2013), Pengaruh Pola Bayangan terhadap Suhu Permukaan Ruang Luar di Perumhaan Taman Cipto Cirebon, Teknik Arsitektur Sekolah Tinggi Teknologi Cirebon. 